\title{
Concern for others: A management attribute of excellent companies
}

\author{
R. Khumalo \\ Graduate School of Business Leadership, \\ University of South Africa, PO Box 329, Pretoria 0003, Republic of South Africa \\ khumar@unisa.ac.za
}

Received October 2000

\begin{abstract}
This paper examines concern for others as an attribute prevalent and commonly engaged in by the most successful companies in Zimbabwe. The attribute has been identified to be, among others, characteristic of these excellent companies and it is possible that the success of these companies is partly attributable to this characteristic. Although it is likely that this attribute contributes to successful performance by companies that apply it, there is a possibility that the achievement of this could be most effective if all the attributes including those that are not discussed here are implemented collectively resulting in a synergistic effect. The singular application of this attribute, concern for others, should nevertheless, be tried by business practitioners because it could offer significant improvements to enterprises of all kinds.
\end{abstract}

\section{Introduction}

Problems plaguing communities can only be alleviated effectively if all stakeholders in society participate in solving them. Dealing with problems of society should not be the prerogative of government alone nor should it be the sole concern of those affected by them. All of us are part of society and what affects society affects each of us one way or another. Whatever we have comes from society. The more we have, therefore, implies that we have made more effective use of societal resources and we, therefore, partly owe our attainment to society. Our responsibility to society increases with the power we have. Many successful companies have shown concern for others as a gesture of attributing to the community what they have gained from it (Khumalo, 1997). Concern for others in this context refers to an organization's care about all its stakeholders such as employees, customers, suppliers and responsibility towards the political arena and the broader community. This attribute was found in the management practices of successful companies in Zimbabwe. According to Martin (1994) customers tend to like businesses that support good causes. The more companies apply themselves to assisting the communities surrounding them, the more they get back from the communities in the long term.

The concept of working together to lessen societal problems collectively is also found in the idea of the African Renaissance. Embodied within the African Renaissance is the principle that African communities that have encountered common problems need to share their resources to solve such problems. It is further believed that growth and development derive from the collective wisdom and experiences of all people in a society (Mbeki, 1997). For instance, this broad concept of collaboration to assist one another and to uplift the less fortunate can be found in the social responsibility policies of well-respected global companies like IBM. IBM's social responsibility policy states three reasons for the company's commitment:

- to contribute to the economic and social well being of the communities in which they operate, thus helping them to become better for IBM to do business.

- $\quad$ to be recognized by government, customers, business partners and IBM's own employees as a leader in effective and enlightened corporate community involvement.

- to improve morale and motivation of their employees through employees' awareness of, support for and involvement in the company activities. (Clutterbuck, Dearlove \& Snow, 1992 : 154).

This paper focuses on one of the attributes discovered within the most successful companies in Zimbabwe - concern for others. The attribute is a form of social responsibility (Khumalo, 1997). An earlier research study examined Zimbabwean companies to undercover the distinctive management attributes of excellent companies. Specifically, it examined how Zimbabwean excellent companies are managed, as well as the distinctive management attributes of Zimbabwean excellent companies.

Concern for others was among the eight management attributes discovered to be characteristic of Zimbabwean 
excellent companies (Khumalo, 1997). The eight management attributes discovered among these companies were that they

- $\quad$ have a participatory style of management

- communicate with all levels of employees

- $\quad$ promote from within;

- train their employees;

- emphasize the production of quality products and services;

- $\quad$ show concern for others;

- $\quad$ place high value on customers; and

- $\quad$ reward good work (Khumalo, 1997).

This present study extends this prior work and focuses on one attribute, concern for others.

\section{Concern for others as an attribute of success for companies}

There is a thin line between the economic and social roles of business. Every business contains within it a social organization. This relationship can be formal - a hierarchical one defined by the institution - or the informal - one that evolves through the attitudes and actions of people. The two types of relationship determine the effectiveness of business (Burke \& Logson, 1996). Welford and Starkey (1996:33) note that the poor image of American business in the 1970s and 1980s adversely affected 'recruitment, prompted government to legislate and made criticism of industry in the media proliferate.' They further contend that businesses that are unpopular in the larger community find themselves seriously disadvantaged when it comes to competing for scarce resources. They are then forced to make things right by either producing higher profits, paying higher wages and salaries or finding other ways of counter balancing their bad reputation or changing their behaviour completely (Welford \& Starkey, 1996: 33). Businesses cannot ignore the communities in which they are established and expect to flourish. The manner in which business views the public, therefore, determines the manner in which the public views it. It has also been found that companies that do not provide opportunities for employees to develop their talents invariably experience high labour turnover and problems of motivation (Haywood, 1994). 'Many companies now take training as a major plank of their business strategy as a way of improving relations with employees and retaining them' (Clutterbuck, Dearlove \& Snow, 1992: 91).

Great progress has been made by businesses in general to collaborate with their communities. These developments have come about as a result of both reactive and pro-active policies (L'Etang, 1995). In the 1950s the marketing concept of business used to put emphasis on only three principles; namely, long-term maximization of profits, consumer orientation and the integration of business activities to attain profitability and the overall satisfaction of consumers (Van der Walt, Strydom, Marx \& Jooste, 1996: 20). However, subsequently an important realization has been made that the marketing concept should include 'the well-being of society - concern for the environment and the society in which the marketing task is to be performed' (Van der Walt, Strydom, Marx \& Jooste, 1996: 20). Strict environmental regulation by a nation has also been found to enhance the competitiveness of companies, thus leading to more exports by the nation (Porter, 1990). As firms invest in environmental equipment and services more jobs are created (Embley, 1993). High standards of product regulations prodding companies into innovating to produce products that are less polluting result in products that are highly valued internationally (Porter, 1990). Philanthropy and business units have joined hands to form strategies that have given companies powerful competitive advantage and hence profitability (Smith, 1994; Kanter, 1999). Companies that help to protect the environment have also been noted for their non-discrimination in hiring and promoting, assisting the homeless, and providing reasonable health facilities for their employees (L'Etang, 1995).

The practice of an enterprise supporting the community in which it exists is also common in the African philosophy of 'Ubuntu', a Zulu term meaning 'humaneness'. This community concept is a typical African way of life that perceives a business community as a community to which the individual belongs. It is a community built on close interpersonal relationships and group interactions held together by a feeling of security and harmony on the part of all its members (Smith, 1991; Khumalo, 1998a).

Ubuntu involves caring, being sympathetic, sensitive to the needs of others, being respectful, considerate, patient and kind (Chinkanda, 1994). The most cherished value in the concept is working together for the common good: 'Umuntu ngumuntu ngabantu', (A person is what he is because of other people). Where the ubuntu and community concept of business are in place, corporate social responsibility programs should be more natural (Khoza, 1994; Wolmarans, 1995). Involvement of business socially would be an acknowledgement by business that it exists because of the community. When social programs are seen in this light, management ought not to expect anything directly from such programs - they are simply a corporate contribution to the overall well being of society (Khoza, 1993; Newman, 1991; Makhudu, 1993). However, the fact remains that a business that concerns itself about its surrounding community generally benefits that community (Burke \& Logson 1996). To confirm this point, Haywood (1994: 17), states that people prefer to buy from and work for those companies that have a good reputation. In this instance, Sainsbury Supermarket in the United Kingdom is quoted as an example of a company that benefits from this principle. The 
company follows policies that reflect its belief in supporting the community.

\section{Method}

This study examines industrial companies quoted on the Zimbabwean Stock Exchange (ZSE). To facilitate an in depth study, a total of seven excellent companies was selected from the seven industry categories. The criterion for selecting the companies to be studied was that they had to be the best financial performers in their industry category. The seven selected companies represented $12 \%$ of the 58 companies quoted on the ZSE. Mining companies were deliberately excluded because international markets largely control the disposal of their products. Consequently, their success or failure may not be attributed to its management alone but also to other international factors such as the setting of prices of mineral products by the international markets.

The International Standard Industrial Classification (ISIC) was used for selecting the companies according to industry type so as to make the sample representative of the Zimbabwean Industry. An excellent company was selected from each category of ISIC after satisfying the criteria discussed below. A company could only be considered for selection as excellent if it was competing with others in the same industry. This was for the purpose of excluding monopolies from the study. The following two sets of criteria were used in selecting the excellent companies:

\section{Financial Criteria}

The four financial criteria used in the study are the ones that encompass those appreciated by Hitt and Ireland, (1987); Johnson, Natarajan, and Rappaport (1985). They are net earnings to turnover, return on net asset value, earnings per share and market capitalization. The choice of financial criteria as a measure of excellence was to indicate that a successful company should be able to generate wealth for its shareholders (Peters \& Waterman, 1982). Such wealth is manifested in high profits earned by the companies as most of the measures listed above would show.

\section{Macroeconomic criteria}

The second set of criteria was based on Zimbabwean government objectives and includes growth in the provision for local employment and growth in export performance. These were used to measure the companies for a period of seven years from 1988 to 1994 for the financial criteria and from 1988 to 1993 for the criteria based on economic conditions. Data for 1994 were not available for the latter type of criteria. The financial data for selecting the sample were derived from the data bank of the Stock Analysts, Data World in Harare whilst the data for macroeconomic criteria were collected from the Confederation of Zimbabwean Industries.

For a company to be selected as the best under the financial criteria, it had to be leading other companies in its category in at least three of the four criteria as listed above for a period of at least four years. Whereas, for a company to be selected as excellent under the criteria based on macroeconomic objectives, it had to have the best results in at least one of the two measures for at least four of the six years.

\section{Interviews and questionnaire}

Following a triangulation approach to data collection, two instruments were used to collect data from the companies. The first of these involved an in-depth interview using a structured questionnaire approach. The second instrument was a semantic differential scaled questionnaire. An interview schedule was used to get responses from chief executives, departmental managers, and skilled, semi-skilled and unskilled employees. Interviewees were placed in these five categories. Altogether a total of 470 people were interviewed and some were interviewed in groups. The interviews lasted two weeks.

The semantic differential scaled questionnaire was used to measure the company orientation towards task versus people and customer versus accounting. This instrument is widely used by researchers (Kerlinger, 1986). See the appendix for a description of the instruments. All the interviewees were given the semantic differential to complete. Before applying the semantic differential and the interview schedule on interviewees, both instruments were tested for reliability and validity in a pilot study on two companies in Butterworth in the Eastern Cape. The reliability coefficient was calculated as

$$
r_{c}=\frac{v_{t}-v_{e}}{v_{t}}
$$

where; $v_{t}$ is the error between individuals and is a measure of internal consistency; and, $v_{e}$ is a measure of the experimental or measurement error.

The resultant coefficient of 0,9708 for the semantic differential scale suggests a high degree of reliable. The content validity for the interview schedule was established through the pilot study.

The employee interviewees were selected with the use of a stratified proportional sampling design. A rate of $18 \%$ was used for selecting employees from each of the strata of skilled, semi-skilled, and unskilled employees. All the departmental managers in the companies were interviewed because the number of departments in most of the companies tended to be six or even less and applying a 
proportional sampling design would not result in a significant sample size. Each company chief executive was also interviewed and given a semantic differential to complete.

Finally, before the interviews began in each company, the mission statement, policies, company reports, and other valuable literature were asked for from each company. This material was used by the researcher to obtain some background information about the companies, and for the purpose of comparing the data with the information in the company literature.

Some of the companies studied had branches in different parts of the country. The interviewees were drawn from either Head Office or from the branch. In some head offices only administrative work was done and there were, therefore, very few employees. It was more appropriate to get to any one of the branches. The assumption adopted by the researcher was that operations for the companies studied are standardized and that there is no significant difference between the employees of the branches and those of Head Office. This assumption was tested in a pilot study on two companies in Bulawayo and the other two in the Eastern Cape Province. The reason for interviewing the chief executive and representatives of all the other levels of employees was to cross check the data obtained from respondents. Notwithstanding, the need in this study for getting perceptions from respondents at different levels of companies, the researcher was of the opinion that certain data about the companies remain the same regardless of who reports on them. It could be possible, however, that the chief executive officers, because of the levels of decisions they make, could be deliberately inclined to paint a brighter picture of the companies. Interviewing the other employees served as a check against such biases and to ensure the validity of the data obtained.

The hypotheses to be tested within and between the companies for all the levels of employees were:

Hypothesis 1: The distribution of task-oriented/peopleoriented management style will be the same in the multiple independently sampled companies.

Hypothesis 2: The distribution of customerorientation/accounting-orientation management style will be the same in the multiple independently sampled companies.

\section{Data analysis}

All the interviews were transcribed. The responses from the interview schedule were content analyzed and the unit of analysis used was the theme. Following a grounded theory approach as advocated by Strauss \& Corbin (1990), themes were identified within the transcribed data. These data were read repeatedly to establish the key thoughts and any important ideas were recorded. Emerging themes through conversation topics, recurring activities and meanings were identified. Determining the boundary of a theme is difficult and this can result in low intra-coder reliability and a second reader was therefore employed to independently search for themes. The two independent findings were compared and reconciled to come up with the most relevant themes. The guiding principle for selecting the themes was that they meet the objectives of the study.

\section{Results}

One of the themes that came out after the data for the interviews were analysed was 'concern for others'. All the companies in the sample were involved in programmes that assist the community. Additionally, they also care for their customers and employees. They donate to charity and support the communities surrounding them in different forms. One company, for example, provides transport to the government for the food relief programme and supplies seedlings to District Councils to plant trees. At the time of this research, the company was also sponsoring a $\mathrm{PhD}$ student studying in the area of timber. Another company also contributes to the Mayor's Christmas Cheer Fund as its gesture of support to the community. The branch manager mentioned the following to describe their donation to the Fund:

During the Christmas Season, in every town where our stores are located, we invite the mayor to get into one of our stores to collect as much as he can of our goods, for three minutes. This is one of the ways we contribute to charity. This fund helps the needy in each town (Branch Manager:OK -J.N.)

The null hypotheses were tested at 5\% level of significance. Given the ranked data, the appropriate test statistic used was the Nonparametric Kruskal-Wallis test which is the equivalent of the parametric one-way analysis of variance test. P-values were used to decide whether to reject or accept the null hypothesis. In significance testing, any pvalue less than the level of significant $(5 \%)$ amounts to a statistically significant result.

For any rejected null hypothesis, multiple paired comparisons were carried out in order to locate the differences. Since there was no exact non-parametric statistical technique for pair wise comparisons, a recommended procedure based on Bonferroni inequalities (which controls overall error rate) was used. To make a decision, one compares the observed difference between mean ranks with the Bonferroni criterion. If the observed difference is greater than the Bonferroni criterion, we reject the null hypothesis and vice versa.

The values of the means in Table 1 indicate that all the companies were perceived by all the respondents to be both 
task-oriented and people-oriented. That is, there was a balance between task orientation and people orientation. A closer examination of Table 2 presenting the results of the test of hypothesis 1 showed that there were no statistically significant differences between companies with regard to task-orientation $(p=0,3291>0,05)$. The results of the test of hypothesis 1 (Table 2) also revealed that there were statistically significant differences between employees with regard to task/people orientation $(p=0,0367<0,05)$. CEOs tended to perceive their companies as more people oriented. This is not an unusual result. The observed difference of 81,03 in Table 3 was in favour of CEO. This meant that CEOs reported higher on people orientation scores than skilled employees. Table 2 confirms this where we observe the mean score for CEOs was 3,0 against 2,4 for skilled employees.

From Table 4 the results of the test of hypothesis 2 showed that there were no statistically significant differences between companies with regard to customer orientation/accounting-orientation $(\mathrm{p}=0,5225)$. The results of the test of hypothesis 2 (Table 5) also revealed that there were no statistically significant differences between employee levels with regard to customer/accounting orientation $(p=0,1377>0,05)$. The values as shown by the means of Table 5 indicate that all the companies were perceived by all the respondents as more customer-oriented than accounting-oriented.

Table 1: Variable: Task oriented/people oriented: company means

\begin{tabular}{|c|c|c|c|}
\hline Company & n & Mean score (Task) & Mean ranks \\
\hline A & 74 & 2,6 & 245,38 \\
B & 80 & 2,5 & 238,06 \\
C & 113 & 2,5 & 238,28 \\
D & 79 & 2,4 & 225,62 \\
E & 60 & 2,6 & 243,69 \\
F & 59 & 2,2 & 199,51 \\
\hline
\end{tabular}

Table 2: Variable: Task/people orientation: means by employee level

\begin{tabular}{|c|c|c|c|}
\hline Employee level & $\mathbf{N}$ & Mean score (Task) & Mean ranks \\
\hline $\mathrm{CEO}$ & 6 & 3,0 & 304,00 \\
\hline Managers & 28 & 2,8 & 272,43 \\
\hline Skilled employees & 103 & 2,4 & 222,97 \\
\hline Semi-skilled employees & 259 & 2,7 & 254,80 \\
\hline \multicolumn{4}{|c|}{ Test of differences between companies } \\
\hline Value of test statistic & DF & $\mathrm{P}$-value & \\
\hline Chi Square $=5,7712$ & 5 & $0,3291 \mathrm{NS}$ & \\
\hline \multicolumn{4}{|c|}{ Test of differences between employee levels } \\
\hline Value of test statistic & DF & P-value & \\
\hline Chi-square $=10,232$ & 4 & $0,0367 \mathrm{~S}$ & \\
\hline \multicolumn{4}{|l|}{$\mathrm{S}=$ Significant at } \\
\hline
\end{tabular}

Table 3: Paired comparison for the difference between employee levels on task/people orientation

\begin{tabular}{|l|c|c|}
\hline \multicolumn{1}{|c|}{ Comparison } & Dif. Mean ranks & Bonferroni* $^{*}$ \\
\hline & & Critical values $^{-1}$ \\
\hline $\mathrm{CEO}=\mathrm{s}$ vs Skilled employees & 81,03 & $45,41 \mathrm{~S}$ \\
\hline $\mathrm{CEO}=\mathrm{s}$ vs Unskilled employees & 82,91 & $155,76 \mathrm{NS}$ \\
\hline $\mathrm{CEO}=\mathrm{s}$ vs Semi-skilled & 49,2 & $158,41 \mathrm{NS}$ \\
\hline
\end{tabular}




\begin{tabular}{|l|c|c|}
\hline $\mathrm{CEO}=$ s vs Managers & 31,57 & $71,28 \mathrm{NS}$ \\
\hline Managers vs Unskilled & 51,34 & $75,04 \mathrm{NS}$ \\
\hline Managers vs Skilled & 49,46 & $84,52 \mathrm{NS}$ \\
\hline Managers vs Semi-skilled & 17,63 & 80,39 \\
\hline Skilled vs Unskilled & 1,88 & 51,10 \\
\hline Skilled vs Semi-skilled & 31,83 & 58,68 \\
\hline Unskilled vs Semi-skilled & 33,71 & 43,94 \\
\hline
\end{tabular}

*Critical Value calculated using 5\% level of significant. 
Table 4: Variable: Customer Oriented Vs Accounting Oriented Company Means

\begin{tabular}{|c|r|c|c|}
\hline Company & N & Mean score (Customer) & Mean ranks \\
\hline \multicolumn{3}{|l|}{} \\
A & 76 & 2,3 & 231,89 \\
B & 81 & 2,6 & 256,78 \\
C & 109 & 2,4 & 228,24 \\
D & 76 & 2,3 & 224,59 \\
E & 60 & 2,3 & 223,48 \\
F & 60 & \multicolumn{2}{l|}{} \\
\hline Kruskal-Wallis (Nonparametric) Test & \\
Test Of Differences Between Companies & P-value & \\
\hline Value of test statistic & DF & $0,5225 \mathrm{NS}$ & \\
\hline Chi-square = 4,1891 & 5 &
\end{tabular}

Table 5: Employee Level Means: Customer Oriented Vs Accounting Oriented

\begin{tabular}{|l|r|c|c|}
\hline \multicolumn{1}{|c|}{ Employee level } & N & Mean score & Mean rank \\
\hline & 6 & & 198,00 \\
CEOs & 26 & 2,0 & 228,10 \\
Managers & 105 & 2,3 & 196,91 \\
Skilled employees & 70 & 2,5 & 237,01 \\
Semi-skilled employees & 255 & 2,1 & 243,92 \\
Unskilled employees & 2,4 & \\
\hline Kruskal-Wallis (Nonparametric) Test & \\
\hline \multicolumn{4}{|c|}{ Test Of Differences Between Companies } \\
\hline Value of Test Statistic & DF & P-Value & \\
\hline Chi-Square =6,9651 & 0,1377 NS & \\
\hline NB: BS = Not Significant at 5\% level
\end{tabular}

All the levels of employees perceived the management style as equally task oriented and people oriented. The result showed that there was no significant difference between the responses of skilled, semi-skilled and unskilled employees of the companies. The companies were perceived to be placing equal importance on the company objectives and employees. They were also seen to be customer oriented. This characteristic is consistent with the attribute of concern for others. Customers and employees come first in these companies as indicated also by the results of the interviews.

\section{Discussion}

The results showed that all the Zimbabwean excellent companies show concern for others through involvement in social responsibility programmes. According to the themes of responses of the interviewees, the seven companies in the study all show an awareness of the communities surrounding them. They contribute in different ways to the uplifting of the communities' standard of living. Evidence of this attribute tallies with the suggestion by Drucker (1987) that every one is an organ of society and exists for the sake of society. In addition to fulfilling its priority task of making profit, every business ought to have an impact on its community and on society in general. Even though jobs and dividends are necessary, they should not be regarded as an end (Drucker, 1987). The attribute of social involvement by Zimbabwean excellent companies is also in accord with the view given by Porter and Van der Linde (1995) that companies of all sizes are discovering that they function best when they merge their business interests with the interest of customers, employees, suppliers, neighbours, investors, and other environments that are affected directly or indirectly by their operations. The Zimbabwe excellent companies are not compelled by law to contribute socially. However, according to Khumalo (1992), they realise that they have an unenforceable obligation to be of assistance to the communities surrounding them. This development in turn boosts business because it is the prosperous communities that increase the economic activity of business in general (Canon, 1992: 32; Burke \& Jeanne, 1996).

Even though this study did not investigate poorly performing companies, it is reasonable to surmise that involvement in social responsibility is the practice of successful companies. It is those companies that have succeeded in satisfying their basic requirements such as profitability that would aspire to satisfy outside stakeholders.

This social involvement by the Zimbabwean excellent companies could also be seen in the light of their cultural background (Khumalo, 1998b) and the African concept of 'ubuntu'. The concept stresses the importance of oneness with the surrounding community: AUmuntu ngumuntu ngabantu - i.e. a person is what he is because of others 
(Khoza, 1993; Mbigi \& Maree, 1995). According to this philosophy, the excellent companies in Zimbabwe owe their status to their neighbourhoods. They are involved in social responsibility programmes to demonstrate their gratitude to the community. They do not expect to receive back anything directly from the community in return for their contribution that is given in to bring about overall well being in the community (Khoza, 1993; Dhlomo, 1991; Chinkanda, 1994). It is clear, therefore, that from an African perspective that, as is the case with the Western one (Martin, 1994; Haywood, 1994), a company which recognises that it is part of the community and contributes towards it will be viewed favourably by the community. This could eventually result in the gaining of a market by the company.

Ubuntu is a normative concept pointing to African traditional values that are regarded highly. These values stand as a measure of any good practice (Khumalo, 1998b). Therefore, those who strive for excellence tend to pattern their approaches after these values. However, one needs to be aware that the pressures of modern society may affect the practice of ubuntu in the long term. Indeed, the endurance of ubuntu in managerial practice may rest upon the ability of African people to remain a collective community. The structure of the African family is declining as a result of the transition from rural life to urban life. Modern economic demands on the African people have pushed them to drift from the norms of ubuntu and yet they have not forgotten them. Those who implement ubuntu values are applauded and regarded as winners. In this paper, 'concern for others' is an aspect of ubuntu and it is a cultural notion translated into a managerial perspective. The opposite of concern for others is concern with self or individualism. Concern for others is a characteristic of collectivist cultures in which people value group achievement versus individualism (Robbins, 1998).

\section{Limitations of this Study}

This study does not claim to have exhausted all the prerequisite ingredients of extraordinary performance. Precautions surrounding the study concern three areas. These are sample size, cause-and-effect relationships and applicability to other organisations and the assurance of sustained extraordinary performance.

The sample size of the study is extremely small in relation to the multitude of no less than 561 companies of all sorts registered in Zimbabwe. Seven of that number represents only $0,015 \%$ of the total. The sample for this study, however, represents $12 \%$ of the companies quoted on the Zimbabwe Stock Exchange (ZSE), the universe from which it was drawn. Only companies quoted on the ZSE were studied and those performing well were selected from each industry in accordance with the International Standard Industrial Classification Code (ISIC). The study was exploratory and intensive; therefore, the sample size of $12 \%$ was considered adequate. The size of the sample for the study was also justified by the fact that the study was concerned with examining the best among many and only a few subjects possess such a quality.
No pretence is made by this study that all ingredients prerequisite to extraordinarily successful performance have been identified with respect to cause-effect relationships defined in terms of the financial criteria (net earnings to turnover, return on net asset value, earnings per share, market capitalisation) and the macroeconomic criteria (provision for local employment, and export performance). For that matter, no assertion can be made that the attribute concern for others, is vital to continued success. Furthermore, it is possible that the eight management attributes discovered in the original study could have a synergistic effect - resulting in successful performance as a result of their collective application. Singling out concern for others as a management attribute to be implemented in a company could possibly not be as effective as applying all the eight characteristics simultaneously.

In spite of the above limitations, the researcher is confident that the attribute 'concern for others' discussed in this paper reveals one of the reasons for the outstanding performance of the sampled seven companies. Furthermore, this attribute may be applicable to a broad range of organisations, business-related or otherwise.

Although reasonably confident that the integration of this finding into less successful companies might enhance their financial and operating performance, the author is not keen to suggest precisely how it should be implemented and incorporated into an existing organisational arrangement. All corporate cultures contain an intricate network of parts and the slightest change of any dimension may lead to unanticipated reactions in other segments. Besides these precautions, the attribute identified in this study strongly suggests that it can contribute to successful performance, and those managers ignoring its existence or relevance do so at some risk.

\section{Conclusion}

This study was conducted on excellent companies and their concern for others and the uplifting of communities around them has been found to be common in all the companies studied regardless of industry category. These companies are socially involved. The social involvement of any other type of company could be the subject of further research. Because concern for others has been discovered to be practised by the excellent companies, it is recommended that even non-excellent performing enterprises both profit making and non-profit making should implement this philosophy. Also, although this was one of the findings on Zimbabwean excellent companies, it could benefit other companies in countries with a socio-economic situation similar to that of Zimbabwe.

\section{References}

Aupperle, K.E. Acar, W. \& Booth D.E. 1986. 'An empirical critique of In search of excellence: How excellent are the excellent companies?' Journal of Management, 12(4): 499-512. 
Burke, L. \& Logson, J. 1996 'How corporate social responsibility pays off,' Long Range Planning, 29(4): 499 - 512.

Chinkanda, E.N. 1994. Shared values and Ubuntu. Paper presented at KONTAK conference on Nation Building at the Human Sciences Research Council, Pretoria.

Clutterback, D., Dearlove, D. \& Snow, D. 1991. Actions speak louder: A management guide to corporate social responsibility. Second Edition. London:

Dhlomo, O. 1991. Paper presented at a Seminar on the Incorporation of Ubuntu into a uniquely South African approach to management - Midrand, South Africa: The Secretariat.

Drucker, P.F. 1987. The frontiers of management: Where tomorrow's decisions are being shaped today. London: Heinemann.

Embley, L. L. 1993. Doing well while doing good: The marketing link between business and non-profit causes. Englewood Cliffs, N.J.: Prentice Hall.

Haywood, R. 1994. Managing your reputation: How to plan and run communications programmes that win friends and build success. New York: McGraw-Hill.

Hitt, M.A. \& Ireland R.D. 1987. 'Peters and Waterman revisited: The unended quest for excellence,' Academy of Management Executive, 1(2): 91-98.

Johnson, B., Natarajan, A. \& Rappaport, A. 1985. 'Shareholder returns and corporate excellence,' Journal of Business Strategy, 52-62.

Kanter, R. M. 1999. 'From spare change to real change', Harvard Business Review, 77(3):122 -132.

Kerlinger, F.N. 1986. Foundations of behavioural research. Third Edition. New York: CBS.

Khoza, R. 1993. The need for an Afrocentric management approach: In Christie, P., Lessem, R. \& Mbigi, L. African management: Philosophies, concepts and applications. Randburg: Knowledge Resources.

Khoza, R. 1994. African humanism. Diepkloof Extension: Ekhaya Promotions.

Khumalo, R. 1992. 'Business with a conscience,' Daily Dispatch, 1 September.

Khumalo, R. 1997. A study of the management attributes of excellent companies in Zimbabwe. Unpublished DBL dissertation.. Pretoria: University of South Africa.

Khumalo, R. 1998a. 'Success in Africa,' Productivity SA. January/February, 24(1): 21 - 24.

Khumalo, R. 1998b. 'Zimbabwe's winning companies,' Productivity SA, 24(2): 32-33.
L'Etang, J. 1995. 'Ethical corporate social responsibility: A framework for managers,' Journal of Business Ethics, 14(2): 125-132.

Makhudu, N. 1993. 'Cultivating a climate of co-operation through Ubuntu,' Enterprise,, August.

Makower, J. 1994. Beyond the bottom line: Putting social responsibility to work for your business and the world. New York: Simon \& Schuster.

Martin, J. 1994. 'Good citizenship is good business: Survey on corporate social responsibility', Fortune, 129(6): 15.

Mbeki, T. 1997. Attracting capital to Africa. The DeputyPresident's address to the Corporate Council Sumit. Johannesburg : Konrad-Adenauer-Stiftung.

Mbigi, L. 1993. The spirit of African management. In Christie, P., Lessem \& Mbigi, L. (Eds.) African management: Philosophies, concepts and applications. Randburg : Knowledge Resources.

Mbigi, L. \& Maree, J. 1995. Ubuntu: The spirit of African transformation management. Randburg: Knowledge Resources.

Newman. 1991. Paper presented at a Seminar on the incorporation of Ubuntu into a uniquely South African approach to management - Midrand, South Africa: The Secretariat.

Peters T. \& Waterman, R. 1982. In search of excellence. New York: Harper \& Row.

Porter, M. 1990. Competitive advantage of nations. New York: Free Press.

Porter, M. \& Van der Linde, C. 1995. 'Green and competitive: Ending the stalemate,' Harvard Business Review, 73(5): $120-123$.

Robbins S. P. 1998. Organisational behavior: Concepts, controversies, applications. Eight Edition. Upper Saddle River, N.J.: Prentice Hall.

Smith, C. 1994. 'The new corporate philanthropy,' Harvard Business Review 7(3): 105, 107.

Smith, R. 1991. Ubuntu in management: Can it really work in South Africa? Presentation given at the Human Sciences Research Council, Pretoria in August.

Strauss, A.L. \& Corbin, J.M. 1990. Basic qualitative research: Grounded theory procedures and techniques. Newbury Park, Calif: Sage Publications.

Van der Walt, A.; Strydom, J.W., Max, S. \& Jooste. C.J. (Eds.) 1996. Marketing management. Third Edition. Kenywyn: Juta \& Co.

Welford, R. \& Starkey, R. (Eds.) 1996. Business and the environment. London: Earthscan Publications. 
Wolmarans, I.S. 1995. Ubuntu as a practical philosophy. Business paper presented at Human Science Research Council, Pretoria. 


\section{APPENDIX}

\section{A. Interview Schedule}

1. What is your philosophy concerning your stakeholders, i.e. customers, suppliers, trade unions and employees?

2. For what customer service is this company renowned?

3. Have you had any problems with the trade unions over any issue concerning the company within the last three years?

4. What activities or projects do you have to assist the community surrounding you?

5. Is there any way in which you assist the government either directly or indirectly?

\section{B. Semantic Differential}

In my company the management style is:

\begin{tabular}{|l|c|c|c|c|c|l|}
\hline & $\begin{array}{c}\text { Very } \\
(1)\end{array}$ & $\begin{array}{c}\text { Fairly } \\
(2)\end{array}$ & $\begin{array}{c}\text { Equally } \\
(3)\end{array}$ & $\begin{array}{c}\text { Fairly } \\
(4)\end{array}$ & $\begin{array}{c}\text { Very } \\
(5)\end{array}$ & \\
\hline Task Oriented & & & & & & People Oriented \\
\hline Customer Oriented & & & & & & Accounting Oriented \\
\hline
\end{tabular}

